\title{
Cetuximab-IR700 Conjugate RM-1929
}

National Cancer Institute

\section{Source}

National Cancer Institute. Cetuximab-IR700 Conjugate RM-1929. NCI Thesaurus. Code C121850.

A chemical conjug ate composed of the dye IR700 linked to cetuximab, a monoclonal antibody directed ag ainst the epidermal growth factor receptor (EGFR), with potential antineoplastic activity. Upon injection, the cetuximab moiety targets and binds to EGFRexpressing tumor cells, resulting in the internalization of the conjugate. Upon localized application of near-infrared (NIR) light, the IR700 dye becomes activated, disrupts the cell membrane and selectively kills the EGFR-expressing tumor cells. EGFR, a tyrosine kinase receptor, is overexpressed in a variety of cancers. 